\title{
The political transnationalism of Ecuadorians in Barcelona, Madrid and Milan: The role of individual resources, organizational engagement, and the political context.*
}

Laura Morales (University of Leicester)

\& Katia Pilati (Université Libre de Bruxelles).

\section{[THIS IS THE VERSION OF THE ARTICLE PUBLISHED IN GLOBAL NETWORKS SUBMITTED TO GLOBAL NETWORKS PRIOR TO THE REVIEW PROCESS. THE FINAL VERSION OF THE ARTICLE CAN BE FOUND AT: http://dx.doi.org/10.1111/glob.12018]} Corresponding author: Laura Morales (1m254@,1e.ac.uk).

Word count: 9,965 (text, references and notes) + 1900 (tables and appendix) + 148 (abstract).

* A previous version of this paper was presented at the conference 'The Transnational Political Practices of Latin American Migrants in Europe', CEDEM, Liège, 11-12 June 2009. We thank the organizer Jean-Michel Lafleur, Paolo Boccagni and the rest of participants for their useful comments.

All the results presented in this paper come from the surveys conducted within the LOCALMULTIDEM project, funded by the $6^{\text {th }}$ Framework Programme of the European Commission (contract CIT5-CT-2005-028802). The project consortium is composed by a team of seven European universities and research institutes, and studies the cases of Budapest, London, Lyon, Madrid, Milan and Zurich. Additionally, the study in Barcelona was conducted with funding from the Spanish Ministry of Education and Science (contract SEJ2005-07733/CPOL). For more information see http://www.um.es/localmultidem and http://www.um.es/capsocinmig. 


\title{
The political transnationalism of Ecuadorians in Barcelona, Madrid and
}

Milan: The role of individual resources, organizational engagement, and the political context.*

Word count: 9,965 (text, references and notes) + 1900 (tables and appendix) + 148 (abstract).

\begin{abstract}
This paper examines the transnational political engagement of Ecuadorians in three European cities: Barcelona, Madrid and Milan. Drawing on previous studies that emphasize the role of organizational and institutional resources for political mobilization - as well as those that take into consideration respondents' resources and the migration process - we analyse the results of a survey conducted with around 300 Ecuadorian individuals in each of these three cities between late-2006 and early-2008. We examine two different dimensions of Ecuadorians' political transnationalism at the individual level: attitudinal and participatory. Contrary to previous scholarship, our results show that recently arrived Ecuadorians and those with more unstable household conditions are more involved in transnational politics. Associational involvement shows multiple effects: engagement in Ecuadorian associations fosters political interest and information towards Ecuador, whereas involvement in any organization promotes electoral transnational politics. The political context is only relevant when accounting for participation in Ecuadorian elections.
\end{abstract}

Keywords: Ecuadorians, transnationalism, political participation, Italy, Spain, mobilization. 


\section{Introduction}

Ecuadorians have become in the past 10 years one of the main immigrant groups in Italy and Spain. Although an increasing number of studies analyse their patterns of (im)migration to these countries, and the social and economic aspects of their integration and transnational practices (see e.g. Jokisch and Pribilsky, 2002; Vallejo, 2004; Avilés, 2005; Herrera, Carrillo and Torres, 2005; Jokisch and Kyle, 2005; Torres, 2005; Pedone, 2006; Boccagni, 2008a), research on their transnational political engagement in these two societies is fairly limited, and there are virtually no cross-national comparative studies.

A recent study of the political transnationalism of Ecuadorians, Moroccans and Turks in seven European cities shows that Ecuadorians are quite engaged in these practices as compared to these other groups (Morales and Morariu, 2011), but important variations among the three south European cities are evident. Yet, there is very little work on Ecuadorians' political transnationalism in general, and in particular of Ecuadorians that have settled in Italy and Spain, the two European countries with the largest Ecuadorian communities after the United States. On the one hand, some studies suggest that the transnational practices of Ecuadorians in the public sphere are fairly limited (Boccagni, 2010). On the other, scholarship on this group has remained underdeveloped because flows of Ecuadorian migration to Europe are relatively recent - starting massively in the early 2000 s - and include a large number of unauthorised migrants. As a result, most studies have focused on non-political transnational practices - which have been rightly deemed as more relevant for an understanding of chain migration, the magnitude of the flows, and their gendered nature - and have employed qualitative approaches to the subject.

Ecuadorians emigrated to Italy and Spain are no exception to the shortage of studies on their transnational political practices. A few exceptions however show that Ecuadorians in Italy feel and are strongly attached to their home country through family ties (Lagomarsino, 2006). Nevertheless, focusing on transnational voting, other scholars argue that they are little interested in broader 
home country issues (Boccagni, 2008b). While these findings provide valuable information, given the dearth of studies on the topic, Boccagni's study is only exploratory - as recognised by himself - and concentrates on the electoral dimension of political transnationalism.

Scholarship on the political transnationalism of Ecuadorian migrants in Spain is - strikingly - even scarcer. Until now, there was no study that specifically addressed how Ecuadorians in Spain maintain links with their homeland political sphere. Some scholarship on Ecuadorian transnational networks in Spain mention associations in passing (eg. Ramírez and Ramírez, 2005 , p. 148ff. \& 162-68) but do not provide systematic information on their transnational practices either. Thus, in essence, there is as yet no detailed study of the nature of Ecuadorians' political transnationalism in either of these two countries, despite their large and growing presence in both.

This article primarily aims at understanding how different national and local contexts, as well as key aspects related to individual political behavior and attitudes - such as the organizational engagement and the resources with which migrants are endowed - might shape the transnational political practices of immigrants (cf. Portes, Guarnizo and Landolt, 1999; Portes, Escobar and Walton Radford, 2007; Martiniello \& Lafleur, 2008). With this purpose, the article describes and analyses the transnational political attitudes and activities of Ecuadorians in three European cities - Barcelona, Madrid and Milan - with results from a survey conducted to between 250 and 300 Ecuadorian individuals in each of these cities.

Our contribution in this article is manifold. First, the article advances the theoretical and empirical research on migrants' political transnationalism by emphasising the need to consider the multidimensionality of these practices, as well as by illustrating how the effects of various factors differ depending on the type of transnational political engagement examined. Though we do not wish to claim that our examination of the multidimensional nature of political transnationalism is the only one possible, we argue that this multidimensionality has not been sufficiently taken into account in previous scholarship and that its 
consideration calls for richer and more nuanced accounts of the nature and extent of immigrants' transnational political practices.

Second, our critical review of the scholarship highlights the importance attributed to the political context, organizational resources - or social capital and immigrant-related characteristics like long-term settlement in the understanding of migrants' political transnationalism. Yet, our findings suggest that these aspects are not related to Ecuadorians' political transnationalism in the ways that these theoretical approaches would lead us to expect. In particular, we show that, despite important differences in political opportunities, only the electoral political transnationalism of Ecuadorians differs in the three cities studied; and that, contrary to previous scholarship in this area, long-term and more settled immigrants are not the most inclined to engage in transnational practices.

Finally, the article shows how focused multi-site quantitative comparative studies of a single immigrant group can complement existing qualitative studies and help move forward the field of migrants' political transnationalism, while at the same time offering novel information about an understudied immigrant group (Ecuadorians) in two understudied reception settings (Italy and Spain).

The paper is organized as follows. First, we suggest that scholarship in this area has sometimes tended to neglect existing theoretical approaches that are consolidated in Sociology and Political Science as helping us to account for immigrants' political engagement. In particular, we draw attention to the potential contribution of scholarship that emphasizes the importance of the political context in the settlement country in shaping transnational engagement, as well as the role of organizations in mobilizing the political involvement of immigrants. Drawing on these theoretical approaches, we put forward specific hypotheses that aim at accounting for the differential transnational political engagement of Ecuadorians in the three cities studied. Secondly, we present the empirical study by providing some background information about Ecuadorian policies towards their citizens emigrating abroad, about Ecuadorians in each of the localities and about the political context of the three cities. We then present the data and methods used to analyse Ecuadorians' transnational political practices and present our findings on the various issues we address. Finally, we 
discuss our results and their implications for the study of political transnationalism.

\section{Explaining transnational politics}

A number of studies has analysed how transnational practices foster (Escobar, 2004; Vertovec, 2004; Portes \& Rumbaut, 2006; Morales and Morariu, 2011) or hinder (Lamm and Imhoff, 1985; Brimelow, 1995; Huntington, 2004) the political engagement of immigrants in the settlement countries, but fewer studies have examined how political transnational practices develop. Some scholars have argued that transnationalism is somehow a 'natural' process and inclination of migrants and their communities (Sayad, 1975), while other studies have instead shown that transnationalism is far from generalised and substantially decreases with second generations (Portes, 2003). Recent scholarship has examined how political transnationalism is affected by the specific socio-demographic and socio-economic characteristics and positions of immigrants. In this regard, Portes, Escobar and Arana (2008, p. 1061) show that 'transnational politics are not a feature of the most recent or poorer immigrants but rather, on the contrary, of settled adults, married, with a higher level of education and with more experience living in American society.' Similarly, Portes, Guarnizo and Landolt (1999, p. 224) advance the hypothesis that immigrant communities with greater average economic resources and human capital (education and professional skills) should register higher levels of transnationalism because of their superior access to the infrastructure that makes these activities possible.'

These studies have provided important and innovative empirical evidence on the impact of individual characteristics on transnational political practices. However, most of them largely overlooked certain contextual aspects commonly acknowledged as important when accounting for the propensity of immigrants to engage in political activities in the countries of settlement: the institutional context of the settlement countries and the organizational structures that immigrants forge. In particular, a well-established strand in the scholarship has shown that the institutional and policy contexts in the settlement country shape 
the opportunities and constraints for immigrants' political engagement more generally, and affect how much this engagement will be transnational in orientation (Koopmans et al., 2005; Bloemraad, 2005). Equally, the recent debates around the notion of 'ethnic civic community' (Fennenma and Tillie, 1999, 2001) highlight how associations constitute resources for political incorporation and mobilization, at the same time that they provide the structures within which that political action is more or less likely to be transnational in nature. Hence, as we discuss at some length in the next few pages, we draw on these two approaches to gain a better understanding of the variations in the transnational political practices of Ecuadorian immigrants across the three cities studied, as - in our opinion - any analysis of transnational political engagement in different settings that ignored these two approaches would be partial and incomplete.

We advocate for a 'minimalist' definition of 'political' transnationalism, and we limit our investigation to those practices - whether directed to the country of residence or the country of origin - that truly link immigrants to the political realm of the countries of origin. ${ }^{1}$ In contrast with scholarship that includes virtually every political activity by migrants in the country of residence as constituting political transnationalism (Portes, Guarnizo and Landolt, 1999; Østergaard-Nielsen, 2003b; Martiniello and Lafleur, 2008), we only consider political engagement that takes place in the country of residence and is oriented towards the country of origin to be indicative of political transnationalism. Thus, we focus on several forms of political involvement related to homeland issues which are, strictly speaking, political, thus relating to political objects or actors, or aiming to change or to resist a change of the existing status quo. Such involvement might be reflected in electoral behavior, in extra-electoral activities - such as contacting political and public authorities - or in expressing an interest towards the political affairs in the country of origin. ${ }^{2}$ Hence, while we do not dismiss broader definitions of political transnationalism as irrelevant - in fact, we think they are very fruitful when investigating the fuzzy boundaries between what is political and what is not, and the transitions from not-so-overtly-political activities to decidely political ones -, we think our 'minimalist' or 'narrow' approach is essential when trying to quantify transnational political practices. 


\section{The Political Opportunity Structures (POS) approach}

Studies on immigrants' transnational practices have shown that the way immigrants' home-country political institutions deal with their emigrating citizens affects the transnational politics they eventually engage in. When migration is motivated by political turmoil in home countries, it may be more likely that immigrants remain politically interested and attached to home country communities. In this light, transnational activities would probably contribute to fill the gap between immigrants and their homeland communities. Additionally, explicit actions may be taken by sending countries as well. As an illustration, granting dual citizenship to their citizens abroad because of an interest of the homeland governments in receiving sustained economic and political contributions, may affect engagement in political transnationalism (Portes, 1999).

While this has shed light on the impact that the political context of immigrants' countries of origin may have on political transnationalism, other studies have indicated that the place of settlement is as well of primary importance for the transnational practices immigrants develop (Bloemraad, 2005; Martiniello \& Lafleur, 2008). Following the POS approach, some have also underlined that the specific institutional context of the place of settlement provided by the citizenship regime that prevails in the receiving countries is also likely to affect immigrant mobilization (Koopmans et al., 2005). Though this framework has been applied mainly to study immigrant mobilization in the receiving countries, the POS approach has also emphasized that migrants' political transnationalism is in many cases a response to the exclusionary citizenship of countries that have put up barriers for migrants' access to the political community (Koopmans et al., 2005, p. 238 ff.). Similarly, Waldinger and Fitzgerald argue that 'states and the politics conducted within their borders fundamentally shape the options for migrant and ethnic trans-state social action' (2004, p. 1178). Though the primary focus of these studies has been on national contexts, research in this field is increasingly pointing to the critical role of subnational or local politics in moulding the socio-economic and political opportunities for transnational practices to emerge and take shape (Bauböck, 
2003).

The organizational approach

In line with a large body of research in political science and political sociology (Knoke, 1982, 1990; Leighley, 1996, 2001), a number of studies indicate that immigrants' political engagement is also connected to their patterns of organizational engagement as well as to the patterns of mobilization and structural connections of migrant and ethnic associations (Togeby, 1999; Jacobs $\&$ Tillie, 2004). Immigration scholars have specifically focused on 'ethnic civic communities' - defined as ethnic organizations and their networks - and have emphasized that engagement in ethnic organizations fosters immigrants' participation in public affairs (Fennema \& Tillie, 1999, 2001; Fennema, 2004).

In this regard, migrants' organizations are expected to provide mobilization cues and resources that contribute to facilitate transnational practices. Migrants' organizations and their networks are not simply privileged actors in the web of transnational practices and fields (Portes, Guarnizo and Landolt, 1999; Itzigsohn, 2000; Østergaard-Nielsen, 2003a), they also crucially shape the access to social capital and the patterns of network embeddedness that allow us to better understand individuals' transnational practices (Portes, 2003; Vertovec, 2003).

Given their centrality in current debates about migrants' political transnationalism, we engage with the aforementioned approaches and assess the following propositions that result from them:

1. 'Closed' national and local contexts of the settlement country are expected to drive immigrants towards more intense and generalized political transnationalism as a result of exclusionary approaches to their political incorporation in the country of residence. As we will explain, the POS is more closed for Ecuadorians in Milan than in the two Spanish cities. Thus, this would make us expect political transnationalism to be more prevalent among Ecuadorians in Milan than in the Spanish cities. 
2. Following the scholarship on organizational resources and mobilization, we expect that engagement in transnational political fields will also be linked to migrants' associational involvement, especially in ethnic organizations. Hence, we hypothesize that where Ecuadorians actively engage in (ethnic) associations they will be more active in transnational politics, regardless of the institutional context.

3. Finally, in line with other studies of individual political transnationalism (Guarnizo, Portes and Haller, 2003) we expect that Ecuadorians who have greater resources at their disposal, have stayed for a longer period in the country, and are legal residents will be more likely to engage in political transnationalism.

\section{Ecuador and its policies towards emigration}

While emigration from Ecuador during the 1990s concerned a few provinces in the South Andes, and was mainly directed to the United States - especially the metropolitan area of New York - the Ecuadorian financial crisis at the end of the 1990s and the dollarization in 2000 had vast implications for migration patterns from Ecuador during the last decade.

In the seven years between 1996 and 2003 Ecuador has sent overseas approximately one third of its economically active population, and most of it arrived to the US and Spain (Acosta, 2004). While before 1998 there were very few Ecuadorians in Europe, between 2000 and 2001 alone around 10 per cent of the economically active population - which was estimated at 5,163,000 individuals in 2000 (Bay et al., 2006: 40-41) - migrated to Spain and Italy (Queirolo Palmas, 2004, p. 321). Some estimates are that around 600,000 Ecuadorians left to live in Spain and 120,000 in Italy (Pedone, 2006, p. 48), and the rest went to other countries of traditional emigration for Ecuadorians - the US and neighbouring Latin American countries. ${ }^{3}$

In this context, Ecuador made important efforts - more or less explicitly driven by the country's interest in remittances and investments that citizens 
abroad usually imply - to support their migrants. In this framework, the Ecuadorian Foreign Ministry specifically addresses Ecuadorian emigrants on their working needs, assists them in legal matters, as well as in the selection procedures of overseas employment recruitment (Ecuadorian Foreign Ministry Department, 2011). In addition to this, specific norms of the Ecuadorian government directly affect the political dimension of its citizens emigrating abroad. External voting has been allowed for Ecuadorians abroad since 2006 through the installation of polling booths in the consulates. Furthermore, dual nationality is allowed by Ecuador (as well as by the Spanish and Italian legislations), so this is not an obstacle for naturalized Ecuadorians to vote in Ecuadorian elections.

Because the Ecuadorian community is so much larger in Spain, the Ecuadorian government tends to be a more important player vis à vis the Spanish government than it is with regard to the Italian one. As an illustration of the strong linkages of Ecuador with Spain, special agreements followed the regulation of migration flows between Spain and Ecuador since the early 2000s through the Unidad de Trabajadores Migratorios, and the latter eventually functions as an intermediary between work offerers and demandants (Ecuadorian Foreign Ministry Department, 2011).

\section{Ecuadorians in Italy and Spain}

In all three cities that we study - Barcelona, Madrid and Milan - Ecuadorians represent one of the major groups of immigration. The proportion of Ecuadorians living in Madrid is double the size of that same group in Barcelona, but they are the most numerous immigrant national community in both cities. In Milan, although the most numerous group is the Filipino, Ecuadorians represented as at $1^{\text {st }}$ January 2006 the fifth largest foreign group that resided in the municipality, despite their recent arrival to Italy. Consequently, by the time we started our fieldwork preparations, Ecuadorians in Barcelona (25,047 individuals) and in Madrid $(104,049)$ represented 1.6 and 3.3 per cent, respectively, of the total population and 8.7 and 18.9 per cent, respectively, of the total resident foreign 
population as at $1^{\text {st }}$ January 2007 (Spanish National Statistics Institute, 2009). Registered Ecuadorians in Milan amounted overall to 12,339 individuals, and constituted 0.95 per cent of the total resident population and 7.6 per cent of the total resident foreign population (Municipality of Milan, 2005). Therefore, the Ecuadorian populations in Barcelona and Milan are much more comparable both in their absolute and relative sizes - and are of outstanding size and proportion in Madrid - the city with the second largest community of Ecuadorian origin or descent in the world.

In terms of their regions of origin, unfortunately, our own surveys did not inquire about this. Yet, the 2007 Spanish National Immigrant Survey conducted by the Spanish National Statistics Institute shows that Ecuadorians who reside in the province of Barcelona primarily originate from the provinces of Guayas (35 per cent), Manabí (14 per cent) and Pichincha (14 per cent), while smaller percentages come from other Ecuadorian provinces. The regional origin of Ecuadorians in Madrid is much more evenly spread across provinces, but the larger groups originate from Pichincha (29 per cent), Guayas (14 per cent) and Loja (12 per cent). In Milan, the existing studies show that most Ecuadorians come from the coastal areas, especially Guayas, where communities of Italian descendants emigrated to Ecuador at the beginning of the 19th century, which may have favored the recent migration flows to Italy (Boccagni, 2008a; Lagomarsino, 2010). The available data from all these sources suggest that, despite the limited information on the region of origin, the respondents' origins are similar in the three cities studied, as they predominantly emigrated from the coastal rather than the Andean or the Amazonian areas of Ecuador.

With respect to the social and economic background of Ecuadorians in such regions - according to Ecuadorian census statistics - in all these provinces the population largely identifies themselves racially as mestizos (around 85 per cent). However, in Guayas and Manabí (coastal provinces) there is a slightly larger proportion of self-identified whites (around 9 per cent) and very few indigenous people ( 1 per cent or less). Instead, the latter constitute around 6 per cent of the population of Pichincha (Ecuadorian National Institute of Statistics and Census, 2008). Economic statistics from these same sources show that 
Manabí and Loja are the most deprived of these provinces, while Pichincha is among the better-off, with Guayas in an intermediate position.

As is common with most Latin American populations in Europe (Queirolo Palmas, 2004), in all three cities, the demographics of the Ecuadorian community are somewhat female-dominated, but more so in Milan with 59 per cent of women; as compared to 55 per cent in Barcelona and 54 in Madrid, where the gender balance of Ecuadorians does not differ much from that of the overall population (52.5 and 53 per cent respectively). ${ }^{4}$ Similarly to other migrant groups in Italy and Spain, Ecuadorian women migrated prior to their male compatriots and found employment mainly in the assistance and care sectors. Furthermore, these are young populations: around one third of Ecuadorians in all three cities 30.5 in Barcelona and Madrid, and 28.5 in Milan - are less than 25 years old. Additionally, in all cities Ecuadorian migrants had lower levels of education than the overall immigrant and native population. Finally, in all three cities Ecuadorian communities include a non-negligible proportion of unauthorized immigrants, much more numerous in Milan than in the two Spanish cities. ${ }^{5}$

\section{The local political contexts of immigrant integration}

The choice of urban settings is particularly propitious to study immigrants, both in the Italian and the Spanish cases. In the area of Milan, most migrants concentrate in the inner city or the municipality of Milan rather than in the proximities and the closest suburbs (ISTAT, 2005, p. 193-94). Equally, the proportion of migrants in Barcelona and Madrid is somewhat higher than the national average - a pattern common to the major urban areas in Spain - and approximately 35 and 77 per cent of all Ecuadorians that live in the provinces of Barcelona and Madrid, respectively, live in the capital cities we study.

Even if several features of the Ecuadorian population are common across cities, the political context of immigrant incorporation substantially varies both at the national and at the local level. At the national level, one of the most notorious differences concerns the rules on citizenship acquisition. While Italy privileges 
an ethnic conception of citizenship that entails that most immigrants will remain foreigners for long, Spain applies a very favorable citizenship regime to all Latin American residents due to its colonial links with the region. ${ }^{6}$ Both Barcelona and Madrid can be classified as open contexts towards the naturalization of Ecuadorians, whereas Milan should be classified as moderately restrictive with substantial consequences on the rates of acquisition of citizenship by Ecuadorians (Cinalli and Giugni, 2011).

Further differences among the three cities are apparent when we focus specifically on the local level. In Barcelona, left-wing parties and coalitions have been governing the city since the first democratic local elections of 1979, whereas in Madrid the centre-right Partido Popular (PP) has been in control of the local government since the early 1990s. In Milan, for more than 10 years a coalition of center-right parties has been in government, including antiimmigrant parties like Lega Nord or Alleanza Nazionale.

The different party coalitions have resulted in very different approaches to migrants' integration and participation. Barcelona has a much more developed and structured policy of citizen participation and consultation than Madrid, as well as a more open and transparent practice of selecting associational representatives to participation bodies, but the context of settlement in Madrid is much more welcoming for migrants' to organise around ethnic and national identities than in Barcelona (Morales et al., 2009). In contrast, Milan constitutes a particularly constraining context for immigrant political integration, as it invests less in immigrant integration and does not actively encourage immigrant associational participation. In this regard, if we consider the budget allocated to immigrant integration between 2006 and 2008 by the Department of Health and Social Services of Milan - the main department responsible for the implementation of immigrant integration policies - the amount spent in this area was around 0.02 per cent of the total local budget (Municipality of Milan, 2006, 2007), while the respective figures for Barcelona and Madrid are 0.22 and 0.27 (Municipality of Madrid, 2006; Municipality of Barcelona, 2006). 


\section{The survey data}

The data we employ in this article derives from a survey of individual Ecuadorians - either born in Ecuador or with at least one parent born in Ecuador - conducted in the three cities within the frame of the project (ANONYMISED). The questionnaires applied in the three cities were identical in the questions that we analyse, and the definition of the target populations was the same. The survey targeted Ecuadorians who had resided in each of the three cities for at least six months and who were at least 15 years of age, regardless of their legal status in the country. Despite targeting both first generation immigrants and second generation Ecuadorians, none of our three surveys captured any second generation respondents, due to the recent arrival of Ecuadorians to Italy and Spain. Yet, our samples include 1.5 generations defined as those immigrants socialized in Italy or Spain, and who arrived before the age of $14 .^{7}$

The survey in Milan was undertaken between November 2006 and April 2007 on a random sample of 300 Ecuadorians. The sample was selected by means of the 'centres of aggregation' method (Blangiardo, 1999) and interviews were conducted by ISMU face to face in public spaces with a questionnaire of approximately 35 minutes duration. ${ }^{8}$ In Barcelona and Madrid, fieldwork took place between January 2007 and February 2008, and was mostly organised inhouse by a fieldwork network purposefully set up for this study by the Universities of (ANONYMISED), resulting in 259 respondents in Barcelona and 291 in Madrid. ${ }^{9}$ All interviews were conducted face-to-face - usually in the respondents' homes - and the questionnaire was of approximately one hour of average duration. Individuals were selected according to their country of birth, and not their nationality. Thus, simple random nominal samples of individuals born in Ecuador were obtained from the municipal statistical offices of each city using the local population registers (Padrón) as the sampling frame, but procedures were in place during fieldwork to detect second generation individuals or erroneous allocations to an immigrant group. ${ }^{10}$ Although the sampling method differed - due to the different availability of suitable sampling frames - the surveys are equivalent or identical in all other aspects and this makes us confident that the results are strictly comparable. 
Furthermore, the characteristics of our samples are consistent with the available statistics on the Ecuadorian population in the three cities. In particular, our samples across cities are fairly similar in what regards the gender composition and how long they have been in the country (around 7 years for all cities), but they differ in other important attributes. If we take a look at Table 1, Ecuadorians in Barcelona are somewhat older (with an average of 40 years of age, as compared to 35 in Madrid and Milan); those residing in Milan have lower educational qualifications, especially compared to those in Barcelona, are more often unemployed (28.7 per cent, as opposed to 16.2 and 18.2 per cent in Barcelona and Madrid), and tend to live with more non-relatives in their households. In Barcelona, 39 per cent of immigrants are engaged in organizations, while 33 per cent are in Madrid and this percentage is by far lower in Milan (23 per cent). In Barcelona and Madrid, Ecuadorians engaged in ethnic organizations, that is, organizations mostly composed of co-nationals, are also more numerous than in Milan. Very importantly, only around 2 per cent of the interviewed Ecuadorians in Milan hold Italian citizenship, whereas between 15 (in Barcelona) and 18 per cent (in Madrid) hold Spanish citizenship. As mentioned, a staggering 19.7 per cent in Milan never had a legal residence permit and the percentage is 3.5 in Barcelona and 2.7 in Madrid. Around 7 per cent of respondents in Madrid and Milan are 1.5 generation Ecuadorians, but only 2.3 per cent are in Barcelona.

\section{TABLE 1 ABOUT HERE}

\section{Results}

Our questionnaire identifies multiple forms of engagement with Ecuadorian politics that tap into the political transnationalism of Ecuadorian immigrants in each of the cities. Table 2 describes the results for each of these items on a cityby-city basis, and includes both attitudinal and behavioural indicators. Clearly, practices and orientations are not equally good measures of the transnational political engagement of immigrants, but the scholarly literature has tended to 
make no clear distinction between the two and, hence, we examine both separately.

Ecuadorians in the three cities show very similar levels of political transnationalism when we focus on attitudes: our results show that they retain only moderate levels of attitudinal engagement with Ecuadorian politics, though they feel highly attached to their homeland. In addition, less than half of them feel well informed about Ecuadorian politics but the least informed are Ecuadorians in Madrid. Finally, more than 50 percent of Ecuadorians in Barcelona and Madrid regularly read newspapers about Ecuador.

As far as voting is concerned, differences are stronger as Ecuadorians in Milan turn out more in Ecuadorian elections than their counterparts in Barcelona and Madrid do. ${ }^{11}$ Beyond voting, rates of non-electoral transnational political action are low in all three cities, especially in Milan, where higher levels of participation in voting seems to be counterbalanced by the lack of active engagement in extra-electoral activities. Overall, there is no single and consistent pattern of political transnationalism that we can identify across the three cities. ${ }^{12}$

\section{TABLE 2 ABOUT HERE}

For this reason, we have examined the dimensionality of all the items of political transnationalism described in Table 2. The results of a factor analysis of all these items (not shown) indicates that there are two clearly distinct dimensions that emerge in similar ways in the three cities: one related to attitudes and cognition (interest, talk, information and newspaper readership), and another that captures turnout in Ecuadorian elections. ${ }^{13}$ Consistently, in the three cities the indicator measuring feelings of attachment to Ecuador - arguably a dubious indicator of transnational engagement - and the indicator of participation in nonelectoral political action are not correlated to all other forms of transnational political engagement. We, thus, focus on the two former indicators: an index of attitudinal-cognitive political transnationalism and the indicator on electoral participation. The scale of attitudinal-cognitive political transnationalism is an additive index that summarises responses to the items on interest, talk, information and newspaper readership (as presented in Table 2), which shows a 
similar consistency (Cronbach's alpha) across the cities. The average values for this index are relatively similar across locations, with Ecuadorians in Barcelona being somewhat more engaged. These small differences across cities suggest that context is not very important for the attitudinal-cognitive component of political transnationalism and that what matters most are individual attributes.

Following past scholarship on the subject (Guarnizo, Portes and Haller, 2003), in order to examine the correlates of the two main dimensions of political transnationalism, we include a number of standard socio-economic variables (gender, age, education, employment situation, household composition), and items related to the immigration process (years since arrival, naturalization, legal status, and the distinction between $1^{\text {st }}$ and 1.5 generations). Additionally, following the social capital and POS approaches, we include items relating to the patterns of associational engagement and social interaction of respondents, as well as their attitudes and orientations towards the institutions and the situation in the country of residence, and control for the city of settlement. The operationalization of each variable is detailed in the Appendix.

Table 3 presents the results of an OLS regression on the scale of attitudinal-cognitive political transnationalism. ${ }^{14}$ The results show that there are few variables that allow us to predict adequately this form of political transnationalism, and not all of our results are consistent with the findings of Guarnizo, Portes and Haller (2003). Our hypothesis on the role of individual resources is not fully confirmed, given that the more educated and those of more recent arrival to the country - and not, as our fourth hypothesis stated, those settled in the country for longer - are more interested in and attentive to Ecuadorian politics. This suggests that, despite the scarcer resources of those more recently arrived, the latter may engage in transnational politics to overcome their feelings of detachment and loneliness which are stronger in the early stages of migration. At the same time, there might be an intentional detachment from Ecuadorian politics precisely by those migrants who have remained the longest abroad, as a reaction of disaffection with the frequent political turmoil in the country. Results on the positive effect of education on political attitudes confirm 
the classical theories of behavioral political participation, namely the socioeconomic status (SES) model (Verba and Nie, 1972).

Those who live in households with a higher proportion of non relatives are also more interested in and attentive to Ecuadorian politics. This is an indicator of the precariousness of living conditions, but also of not having been able to settle completely in the country of residence through family reunification. This reinforces our previous interpretation about the length of stay, as the lack of stable conditions does not help immigrants to feel settled and part of the receiving society, hence contributing to increase feelings of attachment to the homeland country which will often result in a continued interest in Ecuadorian affairs and the inclination to remain informed and talk about Ecuadorian politics with other Ecuadorians.

In contradiction with previous scholarship, important aspects of the migration situation - naturalization, legal status and having been socialized in the country of settlement (for 1.5 generations) - are not related to this dimension of political transnationalism. This suggests that, whereas the legal recognition obtained through legal residency and naturalization is important for engagement in the political sphere of the country of residence (Morales and Pilati, 2011), psychological engagement with homeland politics is more related to the baggage and experience that Ecuadorians bring from their home countries. Curiously, those who feel politically competent - they do not believe that politics is too complicated for them to understand it - are less psychologically engaged in Ecuadorian politics, which indicates that they intentionally detach themselves from Ecuadorian affairs, possibly - as suggested before - because they become increasingly alienated with recurrent political turmoil. ${ }^{15}$

Turning to the core expectations drawn from the 'ethnic social capital' literature, while overall involvement in associations is not significantly related to attitudinal-cognitive political transnationalism, those who join associations mostly composed of other Ecuadorians are more likely to follow Ecuadorian politics. Hence, ethnic 'bonding' within associations - involvement in organizations with a majority of compatriots - fosters this form of political 
transnationalism, while ethnic 'bonding' in informal relations (household and friendships) seems to have no significant effect. ${ }^{16}$ Equally, Ecuadorians who are more trusting of their compatriots are more likely to engage in this form of political transnationalism. This means that ethnic ties forged within Ecuadorian associations, as well as trust towards fellow Ecuadorians, tend to direct immigrants' attention towards Ecuadorian issues. On this point, several studies have shown that organizations are important sources of information, knowledge and political stimuli. Ethnic organizations may thus provide immigrants specific political stimuli and information on Ecuadorian politics and thus be a source of major exposure to information about Ecuadorian politics. Furthermore, organizations mediate collective identities (Johnston and Klandermans, 1995). As a consequence, associations mostly composed of Ecuadorians may also provide shared feelings of belonging to the Ecuadorian community, and ethnic collective identities offer additional resources and motivations for Ecuadorians engaged in these associations to become more informed and interested in Ecuadorian politics than those who do not join Ecuadorian associations.

In contrast to the mixed support of the expectations drawn from the 'ethnic social capital' literature, we find no evidence that clearly asserts the importance of POS in what regards the attitudinal-cognitive dimension of political transnationalism. Attitudes towards the native population and government, and respondents' perceptions of the openness of the situation are not significant, and we find no significant differences among the three cities in this form of transnational political engagement.

\section{TABLE 3 ABOUT HERE}

Moving to electoral political transnationalism, Table 4 shows the results for turnout in Ecuadorian elections. While some results are similar to those found for attitudinal-cognitive political transnationalism (household composition, time since arrival, and the lack of impact of opinions about the openness of the situation and of attachment to the autochthonous population), others substantially differ. 


\section{TABLE 4 ABOUT HERE}

Older respondents are more likely to vote in Ecuadorian elections whereas - consistent with findings showing that transnationalism substantially decreases with second generations (Portes, 2003) - 1.5 generation individuals (socialised in the countries of settlement) are less likely to turn out than those who were socialised in Ecuador. This suggests that immigrants who have been mostly socialized in Ecuador and have migrated only late in life are more concerned about Ecuadorian politics and are thus more inclined to vote in Ecuadorian elections. At the same time, younger people, namely the 1.5 generations, who have been only minimally socialized in Ecuador and thus have less knowledge about Ecuadorian politics, are less likely to vote in Ecuadorian elections.

The impact of social capital variables is quite different than for the attitudinal-cognitive dimension: overall involvement in associations fosters turnout in Ecuadorian elections, while the degree of 'ethnic bonding', both in the public and private domains, and trust in co-ethnics is irrelevant. In contrast to attitudes, transnational actions seem thus affected by more classical variables, namely engagement in organizations, as suggested by the civic voluntarism model (Verba, Schlozman and Brady, 1995). In contrast, the peculiar knowledge and information on Ecuador that ethnic associations more specifically transmit, and that were significant for immigrants to be more informed about Ecuador, are not enough to mobilize immigrants in transnational actions like voting, all other conditions being equal.

Finally, in the case of electoral political transnationalism we find that Ecuadorians in Barcelona and Madrid are significantly less likely to vote in Ecuadorian elections than those who reside in Milan. Therefore, our expectation that political transnational practices should be more common in Milan due to the more 'closed' POS context in Milan is supported for electoral transnationalism. Respondents' opinions about the openness of the context have no significant effect, as it happened for attitudes. This suggests that, in contrast to the significant effect of structural characteristics of the political context, individuals' 
perceptions of the institutions and the situation in the country of residence are not important in affecting transnational political engagement.

\section{Conclusions}

This paper has analysed the political transnationalism of Ecuadorians in Spain and Italy with data from an individual survey in Barcelona, Madrid and Milan. Our results have shown that political transnational practices are multidimensional: it is simplistic to assume that what we commonly refer to as 'political transnationalism' is a unidimensional phenomenon that can be accounted for by a common set of variables. Indeed, our analysis of the political transnationalism of Ecuadorians in Barcelona, Madrid and Milan suggests that there are several forms or 'types' of political transnationalism and that these do not necessarily operate in the same way neither across individuals nor across contexts.

Furthermore, different explanatory factors are required in order to account for different forms of political transnationalism. When we look at the correlates of political transnationalism at the individual level, we find that core variables - such as those related to social capital - have a fundamentally different impact on attitudes and cognition, and on behavior: while engagement in organizations, generally conceived, is significant for transnational voting, only engagement in ethnic organizations affects attitudes towards Ecuadorian politics. When focusing on the impact of resources, like educational attainment, our findings are only marginally more consistent across the two dimensions of political transnationalism. However, our findings are consistent in contradicting previous results about resources accumulated through settlement: Ecuadorians who have recently arrived to Italy and Spain, and those living in households with non-relatives are more likely to become engaged in transnational political attitudes and behaviours. Hence, those living in a more precarious situation, and not those who are most established in the country, are more inclined to engage in transnational political practices. 
Finally, our hypothesis on the role of the political context holds for behavioural political transnationalism (voting), whereas a closed or open political context does not affect the attitudinal and cognitive dimension. Possibly, this is because Ecuadorians in Italy - maybe due to misinformation - do not perceive their environment to be more hostile than what Ecuadorians in Spain think theirs is. In addition, actions like voting generally require more efforts than expressing an interest, reading, talking or becoming informed do, and a constraining environment may thus only affect transnational voting but not the attitudinal and cognitive side of transnationalism linked to being informed about Ecuador, which may be easily accomplished.

Hence, our study partially contradicts theoretical expectations that are common in the literature: that closed contexts induce greater political transnationalism, that bonding social capital leads to greater engagement in homeland politics, and that migrants with more resources have a more transnational outlook. We believe that our results contradict these propositions partly because political transnationalism had been conceived as a unidimensional notion rather than as a multi-faceted set of orientations and behaviours. A more careful specification of the multiple aspects that the term 'political transnationalism' loosely encapsulates should help us move forward in this field, and this article has tried to illustrate how that can be done empirically, and what insights we can get from a more nuanced examination of migrants' political transnationalism.

Finally, future research should incorporate - in a more systematic way than was possible in the scope of our study - the ways in which the previous social positions and experiences of migrants in their countries of origin - as well as the policies enacted by homeland governments towards their emigrants interact with the conditions of settlement and the receiving POS to shape migrants transnational political practices.

\section{References}


ACOSTA, A. 2004 'Ecuador: oportunidades y amenazas económicas de la emigración', Studi Emigrazione, vol. 154, pp. 291-318.

AVILÉS, L. 2005 'Reseña histórica sobre la emigración ecuatoriana a Italia: situación actual y perspectivas', in PONCE LEIVA, J. (ed) Emigración y política exterior en Ecuador. Quito: FLACSO.

BAUBÖCK, R. 2003 'Towards a Political Theory of Migrant Transnationalism', International Migration Review, vol. 37, pp. 700-723.

BAY, G., BRAVO, J. MACADAR, D. AND H. ORELLANA, 2006. Economically active population, Economic Commission for Latin America and the Caribbean (CEPAL)-United Nations.

BLANGIARDO, G. C. 1999 'EUROSTAT-NIDI. Survey on Causes of International Migration. The survey in Italy IRP.CNR. Methodological note on the sampling technique.' Milan: ISMU.

BLOEMRAAD, I. 2005 'The limits of De Tocqueville: How Government facilitates organisational capacity in newcomer communities', Journal of Ethnic and Migration Studies, vol. 31, pp. 865-887.

BOCCAGNI, P. 2008a 'Come funziona un campo sociale transnacionale? Uno studio etnografico sulla migrazione ecuatoriana', $\mathrm{PhD}$ Dissertation, Sociology, University of Trento, Trento.

--- 2008b 'Votare per sentirsi a casa. Il transnazionalismo politico degli immigrati ecuadoriani in Italia', Polis, vol. 22, no. 1, pp. 35-56.

--- 2010 'Private, public, or both? On the scope and impact of transnationalism in immigrants' everyday lives', in BAUBÖCK, R. \& FAIST, T. (eds) Diaspora and Transnationalism. Concepts, Theories and Methods. Amsterdam: Amsterdam University Press.

BRIMELOW, P. 1995 Alien Nation: Common Sense about America's Immigration Disaster. New York: Random House.

CINALLI, M. \& GIUGNI, M. 2011 "Institutional Opportunities, Discursive Opportunities, and the Political Participation of Migrants", in L. Morales \& M. Giugni (eds.) Social Capital, Political Participation and Migration in Europe. Making Multicultural Democracy Work?, Basingstoke, Palgrave Macmillan.

CONSEJO NACIONAL ELECTORAL. 2009 'Resultados Parciales Elecciones 2006, Segunda Vuelta', http://www.cne.gob.ec/index.php?option=com_wrapper\&view=wrapper \&Itemid $=50$, last accessed 19 September 2010.

ECUADORIAN FOREIGN MINISTRY DEPARTMENT. Ministerio de Relaciones Exteriores, Comercio e Integracion, Trabajadores migratorios, Retrieved 4 April 2011 from http://www.mmrree.gob.ec/servicios/trab_migra.asp

ECUADORIAN NATIONAL INSTITUTE OF STATISTICS AND CENSUS. 2008 'Provincial indicators (Indicadores por provincias)', http://www.inec.gov.ec/web/guest/inec est, last accessed 19 September 2010.

ESCOBAR, C. 2004 'Dual Citizenship and Political Participation: Migrants in the Interplay of United States and Colombian Politics', Latino Studies, vol. 2, pp. 45-69. 
FENNEMA, M. 2004 'The Concept and Measurement of Ethnic Community', Journal of Ethnic and Migration Studies, vol. 30, pp. 429-447.

FENNEMA, M. \& TILLIE, J. 1999 'Political participation and political trust in Amsterdam. Civic communities and ethnic networks.' Journal of Ethnic and Migration Studies, vol. 25, pp. 703-726.

--- 2001 'Civic community, political participation and political trust of ethnic groups.' Connections, vol. 24, pp. 26-41.

GRATTON, B. 2007 'Ecuadorians in the United States and Spain: History, Gender and Niche Formation', Journal of Ethnic and Migration Studies, vol. 33, no. 4, pp. 581 - 599.

GUARNIZO, L. E., PORTES, A. \& HALLER, W. J. 2003 'Assimilation and Transnationalism: Determinants of Transnational Political Action among Contemporary Immigrants', American Journal of Sociology, vol. 108, pp. 1211-1248.

HERRERA, G., CARRILlO, M. A. C. \& TORRES, A. 2005 'La migración ecuatoriana. Transnacionalismo, redes e identidades'. Quito: FLACSO.

HUNTINGTON, S. P. 2004 Who are we? The challenges to America's national identity. New York: Simon \& Schuster.

ISMU. 2007 'L'immigrazione straniera nella provincia di Milano. Anno 2007', http://www.ismu.org, last accessed 14 October 2010.

ISTAT. 2005 'Gli stranieri in Italia. Analisi dei dati censuari'. Roma: ISTAT.

--- 2009 'Online datababase', http://demo.istat.it/altridati/rilbilstra/, last accessed 12 April 2009.

ITZIGSOHN, J. 2000 'Immigration and the boundaries of citizenship', International Migration Review, vol. 34, pp. 1126-1154.

JACOBS, D. \& TILLIE, J. 2004 'Introduction: Social Capital and Political Integration of Migrants', Journal of Ethnic and Migration Studies, vol. 30, pp. 419-427.

JOHNSTON, H. \& KLANDERMANS, B. 1995 Social movements and culture. Minneapolis: University of Minnesota Press.

JOKISCH, B. \& KYLE, D. 2005 'Transformations in Ecuadorian transnational migration 1993-2003', in HERRERA, G., CARRILLO, M. A. C. \& TORRES, A. (eds) Ecuadorian Migration: transnationalism, networks and identities. Quito: FLACSO.

JOKISCH, B. \& PRIBILSKY, J. 2002 'The Panic to Leave: Economic Crisis and the "New Emigration" from Ecuador', International Migration, vol. 40, no. 4, pp. 75-102.

KNOKE, D. 1982 'Political mobilization by voluntary associations', Journal of Political and Military Sociology, vol. 10, pp. 171-182.

--- 1990 'Networks of political action: toward theory construction', Social Forces, vol. 68, pp. 1041-1063.

KOOPMANS, R., et al. 2005 Contested Citizenship. Immigration and Cultural Diversity in Europe. Minneapolis: University of Minnesota Press.

LAGOMARSINO, F. 2006 Esodi e approdi di genere. Famiglie transnazionali e nuove migrazioni dall'Ecuador. Milano: Franco Angeli.

--- 2010 'Migrazione ecuadoriana e bisogni insoddisfatti di cura. Uno sguardo iniziale', CeSPI Working Papers. Roma: CeSPI.

LAMM, R. D. \& IMHOFF, G. 1985 The immigration time bomb. The fragmenting of America. New York: Dutton. 
LEIGHLEY, J. E. 1996 'Group membership and the mobilisation of political participation', Journal of Politics, vol. 58, pp. 447-463.

--- 2001 Strength in numbers? The political mobilization of racial and ethnic minorities. Princeton \& Oxford: Princeton University Press.

MARTINIELLO, M. \& LAFLEUR, J.-M. 2008 'Towards a transatlantic dialogue in the study of immigrant political//transnationalism', Ethnic and Racial Studies, vol. 31, pp. 645-663.

MORALES, L., GONZÁLEZ, A. \& JORBA, L. 2009 'Políticas de incorporación y asociacionismo de la población de origen inmigrante a nivel local.' IN ZAPATA-BARRERO, R. (Ed.) Políticas de gobernabilidad de la inmigración en España. Barcelona, Ariel.

MORALES, L. \& MORARIU, M. (2011) Is 'Home' a Distraction? The Role of Migrants' Transnational Practices in their Political Integration into Receiving-Country Politics. IN MORALES, L. \& GIUGNI, M. G. (Eds.) Social Capital, Political Participation and Migration in Europe. Making Multicultural Democracy Work? Basingstoke, Palgrave.

MUNICIPALITY OF BARCELONA. 2006 'Budgetary Report 2005 (Compte General 2006, Ajuntament de Barcelona)'. Barcelona: Municipality of Barcelona.

MUNICIPALITY OF MADRID. 2006 'Budget for 2005 (Contabilidad General, Presupuesto Ejecutado Ayuntamiento de Madrid 2005)'. Madrid: Municipality of Madrid.

MUNICIPALITY OF MILAN. 2005 'Population Statistics', http://www.comune.milano.it/portale/wps/portal/searchresultdetail?WCM GLOBAL_CONTEXT=/wps/wcm/connect/ContentLibrary/ho+bisogno + di/ho+bisogno + di/banche + dati + e + statistiche dati + statistici + relativi + all a+popolazione, last accessed 10 October 2009.

--- 2006 'Budgetary report 2006 (Comune di Milano. Rendiconto della gestione. Esercizio 2006.)', http:/www.comune.milano.it/portale/wps/portal/CDM?WCM GLOBAL CONTEXT=/wps/wcm/connect/contentlibrary/Ho per cent20bisogno per cent20di/Ho per cent20bisogno per cent20di/Sostegno per cent20e per cent20assistenza_Pubblicazioni_Piano per cent20di per cent20Zona per cent20dei per cent20servizi per cent20sociali per cent202006 per cent $202008 \&$ categId $=$ com.ibm.wor, last accessed 15 October 2009.

--- 2007 'Plan for the interventions and the social services 2006-2008 (Piano di Zona degli interventi e dei servizi sociali 2006-2008)', http://www.comune.milano.it/portale/wps/portal/CDM?WCM_GLOBAL CONTEXT=/wps/wcm/connect/contentlibrary/Ho per cent20bisogno per cent20di/Ho per cent20bisogno per cent20di/Sostegno per cent20e per cent20assistenza_Pubblicazioni_Piano per cent20di per cent20Zona per cent20dei per cent20servizi per cent20sociali per cent202006 per cent $202008 \&$ categId $=$ com.ibm.wor, last accessed 22 April 2009.

ØSTERGAARD-NIELSEN, E. 2003a 'The politics of migrants' transnational political practices', International Migration Review, vol. 37, pp. 760-786.

--- 2003b Transnational politics. Turks and Kurds in Germany. London \& New York: Routledge.

PEDONE, C. 2006 Tu siempre jalas a los tuyos. Estrategias migratorias y poder. Quito: Editorial Abya-Yala. 
PORTES, A. 1999 'Conclusion: Towards a new world: the origins and effects of transnational activities' Ethnic and Racial Studies 22/2: 463-477.

PORTES, A. 2003 'Conclusion: Theoretical Convergencies and Empirical Evidence in the Study of Immigrant Transnationalism', International Migration Review, vol. 37, pp. 874-892.

PORTES, A., ESCOBAR, C. \& ARANA, R. 2008 'Bridging the gap: transnational and ethnic organizations in the political incorporation of immigrants in the United States', Ethnic and Racial Studies, vol. 31, no. 6, pp. 1056 - 1090.

PORTES, A., ESCOBAR, C. \& WALTON RADFORD, A. 2007 'Immigrant Transnational Organizations and Development: A Comparative Study', International Migration Review, vol. 41, pp. 242-281.

PORTES, A., GUARNIZO, L. E. \& LANDOLT, P. 1999 'The study of transnationalism: pitfalls and promise of an emergent//research field', Ethnic and Racial Studies, vol. 22, pp. 217-237.

PORTES, A. \& RUMBAUT, R. G. 2006 Immigrant America. A Portrait, 3rd ed. Berkeley: University of California Press.

QUEIROLO PALMAS, L. 2004 'Oltre la doppia assenza. Percezioni di cittadinanza fra gli ecuadoriani di Genova', Studi Emigrazione, vol. 154, pp. 319-340.

RAMÍREZ GALLEGOS, F. \& RAMÍREZ, J. P. 2005 La estampida migratoria ecuatoriana. Crisis, redes transnacionales y repertorios de acción migratoria, 2nd updated ed. Quito: Centro de Investigaciones CIUDAD.

SAYAD, A. 1975 'Elghorba: le mécanisme de reproduction de l'émigration', Actes de la Recherche en Sciences Sociales, vol. 2, pp. 50-60.

SPANISH NATIONAL STATISTICS INSTITUTE (INE). 2009 'Statistical analysis of the local population register (Padrón)', http://www.ine.es/jaxi/menu.do?type=pcaxis\&path $=\% 2 \mathrm{Ft} 20 \% 2 \mathrm{Fe} 245 \&$ fil $\mathrm{e}=$ inebase $\& \mathrm{~L}=$, last accessed 15 October 2009.

TOGEBY, L. 1999 'Migrants at the polls: an analysis of immigrant and refugee participation in Danish local elections', Journal of Ethnic and Migration Studies, vol. 25, pp. 665-684.

TORRES, F. 2005 'La inmigración ecuatoriana en España y su proceso de inserción', in HUMANOS, P. A. D. D. (ed) Migración, desplazamiento forzado y refugio. Quito: UASB, FEPP.

VALLEJO, A. 2004 'El viaje al norte. Migración transnacional y desarrollo en Ecuador', in ESCRIVÁ, Á. \& RIBAS, N. (eds) Migración y desarrollo. Estudios sobre remesas y otras prácticas transnacionales en España. Córdoba: Instituto de Estudios Sociales de Andalucía.

VERBA, S., \& N., NIE. 1972. Participation in America: Political democracy and social equality. New York: Harper and Row.

VERBA, S., K. SCHLOZMAN, AND \& H. BRADY. 1995. Voice and Equality: Civic Voluntarism in American Politics. Cambridge, MA: Harvard University Press.

VERTOVEC, S. 2003 'Migration and other modes of transnationalism: towards conceptual cross-fertilization', International Migration Review, vol. 37, pp. 641-665.

--- 2004 'Migrant Transnationalism and Modes of Transformation', International Migration Review, vol. 38, no. 3, pp. 970-1001. 
WALDINGER, R. \& FITZGERALD, D. 2004 'Transnationalism in Question', American Journal of Sociology, vol. 109, no. 5, pp. 1177-1195. 


\section{TABLES}

Table 1. Descriptives of independent variables.

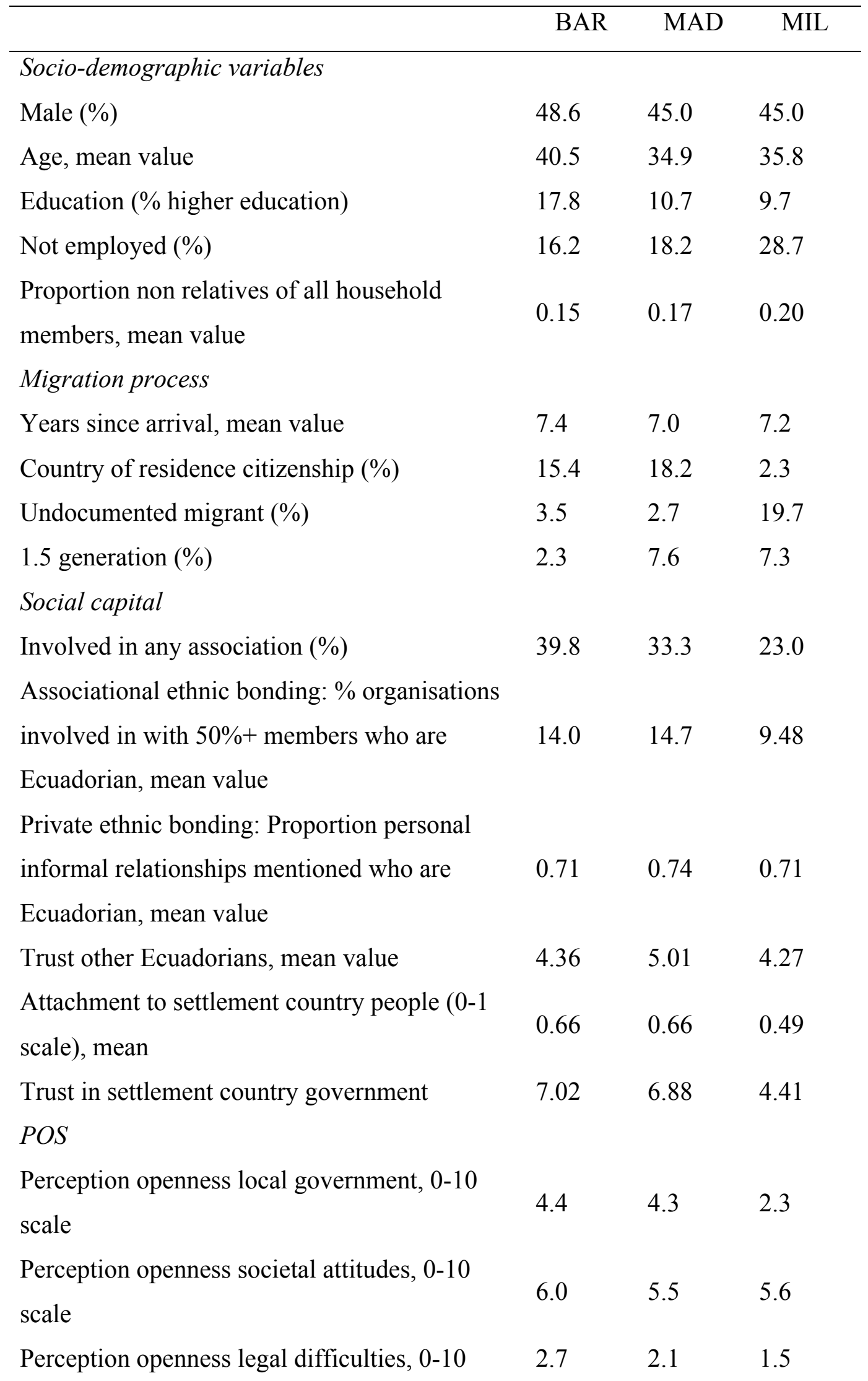


scale

Other control variables

$\begin{array}{llll}\text { Internal political efficacy } & 0.66 & 0.71 & 0.71\end{array}$

Number of cases (minimum, maximum) $\quad 241,259 \quad 278,291 \quad 284,300$ 
Table 2. The Political Transnationalism of Individual Ecuadorians

\begin{tabular}{|c|c|c|c|}
\hline & BAR & MAD & MIL \\
\hline \multicolumn{4}{|l|}{ Attitudes } \\
\hline Very or fairly interested in Ecuadorian politics $(\%) *$ & 56 & 50 & 53 \\
\hline Regularly talks about Ecuadorian politics (\%)* & 51 & 45 & 42 \\
\hline Attachment to Ecuador (average on $0-10$ scale) & 8.9 & 8.9 & 9.2 \\
\hline \multicolumn{4}{|l|}{ Information } \\
\hline $\begin{array}{l}\text { Feels reasonably or well informed about public affairs in } \\
\text { Ecuador }(\%) *\end{array}$ & 40 & 27 & 43 \\
\hline \multicolumn{4}{|l|}{$\begin{array}{l}\text { Scale of attitudinal-cognitive political } \\
\text { transnationalism (includes items with *) }\end{array}$} \\
\hline Average value (0-1 range) & 0.5 & 0.45 & 0.43 \\
\hline Cronbach's alpha of scale & 0.66 & 0.66 & 0.79 \\
\hline \multicolumn{4}{|l|}{ Political participation } \\
\hline Voted in previous Ecuadorian legislative elections (\%) & 29 & 27 & 39 \\
\hline Contacted a politician $(\%)^{+}$ & 0.4 & 0.7 & 0.3 \\
\hline Contacted a government official $(\%)^{+}$ & 1.9 & 1.0 & 0.3 \\
\hline Worked in a political party $(\%)^{+}$ & 0.8 & 0.0 & 0.0 \\
\hline Worked in an action group $(\%)^{+}$ & 0.0 & 0.7 & 0.0 \\
\hline Use of badge, sticker, poster $(\%)^{+}$ & 0.4 & 0.3 & 0.0 \\
\hline Attended a public demonstration $(\%)^{+}$ & 0.0 & 0.7 & 0.0 \\
\hline Boycotted a product for political reasons $(\%)^{+}$ & 0.0 & 0.3 & 0.0 \\
\hline Bought a product for political reasons $(\%)^{+}$ & 0.4 & 0.7 & 0.0 \\
\hline Donated money to political causes $(\%)^{+}$ & 0.0 & 0.3 & 0.3 \\
\hline Took part in a strike $(\%)^{+}$ & 0.0 & 0.3 & 0.0 \\
\hline Contacted the media $(\%)^{+}$ & 0.8 & 1.0 & 0.3 \\
\hline Contacted a solicitor for non-personal reasons $(\%)^{+}$ & 0.0 & 0.0 & 0.7 \\
\hline $\begin{array}{l}\text { Participated in any of the above forms of non-electoral } \\
\text { political action on issues related to Ecuador }(\%)\end{array}$ & 4 & 6 & 1 \\
\hline (Number of cases) & 259 & 291 & 300 \\
\hline
\end{tabular}


Table 3. The correlates of the attitudinal-cognitive political transnationalism of Ecuadorians (OLS Regression)

\begin{tabular}{|c|c|c|c|}
\hline & B & Std. Error & Beta \\
\hline \multicolumn{4}{|l|}{ Socio-demographic variables } \\
\hline Male & .030 & .027 & .042 \\
\hline Age & .001 & .001 & .030 \\
\hline Education & .126 & $.055 * *$ & .090 \\
\hline Not employed & .013 & .035 & .014 \\
\hline Proportion non relatives of all household members & .102 & $.052 *$ & .074 \\
\hline \multicolumn{4}{|l|}{ Migration process } \\
\hline Years since arrival & -.011 & $.004 * * *$ & -.124 \\
\hline Country of residence citizenship & .014 & .044 & .013 \\
\hline Undocumented migrant & .018 & .050 & .015 \\
\hline 1.5 generation & -.005 & .068 & -.003 \\
\hline \multicolumn{4}{|l|}{ Social capital } \\
\hline Involved in any association (dummy) & -.029 & .035 & -.038 \\
\hline $\begin{array}{l}\text { Associational ethnic bonding: } \% \text { organisations involved } \\
\text { in with } 50 \%+\text { members who are Ecuadorian }\end{array}$ & .002 & $.000 * * *$ & .149 \\
\hline $\begin{array}{l}\text { Private ethnic bonding: Proportion personal informal } \\
\text { relationships mentioned who are Ecuadorian }\end{array}$ & .046 & .048 & .037 \\
\hline Trust other Ecuadorians & .014 & $.005^{* *}$ & .098 \\
\hline Attachment to settlement country people, $0-1$ scale & -.059 & .060 & -.042 \\
\hline Trust in settlement country government & -.004 & .006 & -.028 \\
\hline \multicolumn{4}{|l|}{ POS } \\
\hline Perception openness local government, $0-10$ scale & .006 & .005 & .048 \\
\hline Perception openness societal attitudes, $0-10$ scale & -.003 & .005 & -.019 \\
\hline Perception openness legal difficulties, $0-10$ scale & -.003 & .009 & -.012 \\
\hline Barcelona & .046 & .039 & .060 \\
\hline Madrid & .024 & .038 & .032 \\
\hline \multicolumn{4}{|l|}{ Other control variables } \\
\hline Internal political efficacy & -.161 & $.040 * * *$ & -.157 \\
\hline (Constant) & .458 & $.106^{* * *}$ & \\
\hline Adjusted $\mathrm{R}^{2}$ & \multicolumn{2}{|c|}{0.08} & \\
\hline (Number of cases) & 70 & & \\
\hline
\end{tabular}

Dependent Variable: Scale of attitudinal-cognitive political transnationalism.

$\mathrm{p} \leq * 0.10 * * 0.05 * * * 0.01$ 
Table 4. The correlates of the electoral political transnationalism of Ecuadorians

(Logistic Regression)

\begin{tabular}{|c|c|c|c|}
\hline & B & Std. Error & $\operatorname{Exp}(\mathrm{B})$ \\
\hline \multicolumn{4}{|l|}{ Socio-demographic variables } \\
\hline Male & -.001 & .178 & .999 \\
\hline Age & .030 & $.009 * * *$ & 1.031 \\
\hline Education & -.095 & .357 & .909 \\
\hline Not employed & -.198 & .235 & .820 \\
\hline Proportion non relatives of all household members & .611 & $.330 *$ & 1.843 \\
\hline \multicolumn{4}{|l|}{ Migration process } \\
\hline Years since arrival & -.091 & $.039 * *$ & .913 \\
\hline Country of residence citizenship & -.378 & .330 & .685 \\
\hline Undocumented migrant & -.281 & .324 & .755 \\
\hline 1.5 generation & -2.564 & $1.062 * *$ & .077 \\
\hline Attachment to settlement country people & -.689 & $.396^{*}$ & .502 \\
\hline \multicolumn{4}{|l|}{ Social capital } \\
\hline Involved in any association (dummy) & .642 & $.231 * * *$ & 1.900 \\
\hline $\begin{array}{l}\text { Ethnic bonding: } \% \text { organisations involved in with } 50 \%+ \\
\text { members who are Ecuadorian }\end{array}$ & -.002 & .003 & .998 \\
\hline $\begin{array}{l}\text { Private ethnic bonding: Proportion personal informal } \\
\text { relationships mentioned who are Ecuadorian }\end{array}$ & .078 & .325 & 1.081 \\
\hline Trust other Ecuadorians & .031 & .035 & 1.031 \\
\hline Trust in settlement country government & .013 & .042 & 1.013 \\
\hline \multicolumn{4}{|l|}{$P O S$} \\
\hline Perception openness local government, $0-10$ scale & .032 & .036 & 1.032 \\
\hline Perception openness societal attitudes, $0-10$ scale & -.038 & .036 & .963 \\
\hline Perception openness legal difficulties, $0-10$ scale & .030 & .058 & 1.031 \\
\hline Barcelona & -1.034 & $.268 * * *$ & .356 \\
\hline Madrid & -.772 & $.258 * * *$ & .462 \\
\hline \multicolumn{4}{|l|}{ Other control variables } \\
\hline Internal political efficacy & .011 & .268 & 1.011 \\
\hline Constant & -.618 & .734 & .539 \\
\hline Nagelkerke $\mathrm{R}^{2}$ & 0.16 & & \\
\hline (Number of cases) & 702 & & \\
\hline
\end{tabular}


APPENDIX: Operationalization of main variables.

Gender: A dummy variable taking the value 1 for males and 0 for females. Age: A ratio variable that records the age of respondents.

Education: Item wording: "What is the highest level of education you have achieved?" The original categories of answer are: 1 "not completed primary education", 2 "primary education or first stage of basic education", 3 "Lower level secondary education or second stage of basic education", 4 "upper secondary education", 5 "post secondary, non-tertiary education", 6 "first and second stage of tertiary education". From the original ordinal scale we computed a variable ranging between 0 and 1 . The variable was obtained by subtracting 1 to the original categories and dividing by 5 .

Employment situation (unemployed): Item wording: "Which of these descriptions best describes your situation in the last seven days? Please, select only one." The response set was: 01. In paid work; 02. in education (not paid for by employer); 03. Unemployed and actively looking for job; 04. unemployed, wanting a job but not actively looking for it; 05 . permanently sick or disabled; 06. retired; 07. In community or military service; 08. doing housework, looking after children or other persons; 09. other. A dummy variable (unemployed) was created that identified with a value of 1 those that had chosen category 03, and assigned a value of 0 to all other respondents.

Has citizenship of country of residence: This is a dummy variable taking the value 1 for respondents who have the citizenship of the country of residence and 0 for those who do not. Respondents were asked in which country or countries they hold citizenship (up to 3 possible countries). Respondents who declared they hold a citizenship corresponding to the country of residence were considered as being residence country nationals.

Years since arrival: A ratio scale variable indicating how many years the respondent has lived in the country. The variable was created on the basis of the year respondents moved to the country and the year when the interview took place.

1.5 generation: This is a dummy variable taking the value 1 for first generation of migrants who are born abroad and socialized in the host country. To create this variable we combined the information on the respondent's country of birth 
(Ecuador), citizenship at birth (Ecuador) and the respondent's age of arrival to the host country. Respondents of the first generation who arrived before the age of 14 years old to the country of residence assigned a value of 1 .

Undocumented: Dummy variable that takes the value of 1 if the individual declares that $\mathrm{s} / \mathrm{he}$ never had a legal residence permit.

Involved in any association: a dummy variable taking the value 1 for respondents who are involved in volutary associations and 0 for those who are not. It measures membership or participation in 18 types of association. The variable takes the value 1 if respondents declared to be members (currently or currently and in the past) of at least one type of organization or to have participated in any activity arranged by at least one type of organization in the last 12 months, and 0 if not so.

Social trust: Item wording: 'Generally speaking, would you say that most people can be trusted, or that you can't be too careful in dealing with people?' Response categories: a score in a 0 to 10 scale in which 0 meant 'you can't be too careful' and 10 'most people can be trusted'.

Associational ethnic bonding: A continuous index that ranges from 0 to 1 and is the proportion of associational involvements the respondent has reported in which 50 per cent or more of the co-members are co-ethnics.

Private ethnic bonding: Item wording: "Looking back to the last few months, we would like to know the people with whom you talk and interact frequently: close family, close workmates, close friends, close neighbours, close acquaintances, etc. Can you think of anyone? Is he/she of the same [ethnic/national group] as you?" This variable records the proportion of the relationships the respondent holds (up to 5) that are with co-ethnics.

Attachment to 'host-country' people: Item wording: 'Now I would like to ask you how attached you feel to different places and groups of people. [CATI: In a scale from 0 to 10 , where 0 means no attachment at all and 10 means very strong attachment] How attached are you to..."

Trust in settlement country government: Item wording: "In the following, we name some public institutions in [CITY], [COUNTRY] and Europe. Specify, to what extent you do, or do not, trust them. Please use a scale from 0 (I do not trust at all) to 10 (I totally trust)." 
Trust in one own's ethnic group members: Item wording: "And what about Ecuadorians, would you say that most Ecuadorian people can be trusted, or that you need to be always somewhat suspicious in dealing with them? Please use a scale from 0 (I do not trust at all) to 10 (I totally trust)."

Internal political efficacy: The index of internal efficacy is an ordinal scale based on a five-point item with responses to the statement 'Sometimes politics is so complicated that people like me do not understand anymore what is going on'). Perception of openness of the local government: The average score on a 0-10 $(0=$ totally disagree, $10=$ totally agree $)$ scale of responses to the following two items: 'The local government does a lot to improve the way in which [immigrant/ethnic] residents live in [HOST-CITY]' and 'It is fairly easy for [immigrant/ethnic] residents to make their voice heard to the local government'. Perception of openness of the societal attitudes: as above for the items: 'Getting a job in [HOST-COUNTRY] is very difficult for immigrants', 'Immigrants/ethnic minorities have great difficulties in [HOST-COUNTRY] to get access to public health', and 'The [HOST-COUNTRY] society has a very negative attitude towards [immigrant/ethnic members]'. The scores were reversed so that a value of 10 meant a perception of greater openness and a value of 0 of greater closure.

Perception of openness of the legal difficulties: as above for the items: ' People who want to come to [HOST-COUNTRY] from abroad face too many difficulties to obtain a legal residence or work permit' and 'Foreigners living in [HOST-COUNTRY] can easily bring their families with them once they have settled down'. 


\section{NOTES}

1 See (REF ANONYMISED) for a more detailed conceptual discussion of 'political' transnationalism.

${ }^{2}$ For example, Martiniello and Lafleur (2008, p. 653) argue that 'Immigrant political transnationalism covers any political activity undertaken by migrants who reside mainly outside their homeland and that is aimed at gaining political power or influence at the individual or collective level in the country of residence or in the state to which they consider they belong.' This is, in our opinion, too wide a definition that assumes that every political act by immigrants in their countries of residence is transnational in nature.

${ }^{3}$ However, the Spanish rolling local population register (Padrón), as at $1^{\text {st }}$ January 2008, counted only 458,437 individuals born in Ecuador, of which 415,535 were non-Spanish nationals. The figures have not increased much since $2006(456,641)$. It seems unlikely that there ever were 600,000 Ecuadorians residing in Spain, and it is more likely that 500,000 is closer to the real figure, given that the Spanish local population registers include both regular and irregular immigrants. According to the Italian National Statistical Office (ISTAT, 2009), as at $1^{\text {st }}$ January 2008, there were 73,235 Ecuadorians residing in Italy. However, the statistics on residents derive from population registers that only include foreigners enlisted on them, and these exclude both the regular immigrants without a permanent address as well as all irregular immigrants. The latter is particularly relevant for Ecuadorians, as in Milan our survey results indicate that around 20 per cent of respondents never had a legal residence permit.

${ }^{4}$ The dominant female presence among Ecuadorians in Europe is not such in the US, as migration chains have been differently gendered depending on the receiving country (Pedone, 2006, Gratton, 2007).

${ }^{5}$ Unauthorized Ecuadorians in Milan were estimated to constitute 24 per cent of all residents of that group in the Municipality of Milan as at $1^{\text {st }}$ July 2006 (ISMU, 2007: 53-54). There are no equivalent estimates for Barcelona and Madrid, but in our surveys around 4 per cent of all interviewed Ecuadorians in Barcelona and Madrid recognise they never had a permit, while in Milan that same percentage rises to 20 per cent, hence lending credibility to the previous figures for the latter city.

${ }^{6}$ In Italy citizenship rules are based on the principle of jus sanguinis, and the acquisition of citizenship by residence requires 10 years of legal residence. In Spain, the general rule is also 10 years of residence, but Latin American immigrants are only required 2 years.

${ }^{7} \mathrm{~A}$ full description of the samples and of the main socio-demographics of respondents can be found on the report about these surveys at (URL REFERENCE ANONYMISED).

${ }^{8}$ The sample is designed to achieve representativeness of the migrant population - including undocumented migrants - assuming that each migrant entertains some relationship with some aggregation centers or gathering places identified in Milan. Based on the assumption that the sample is large enough, and that the relative importance of each center is known, the technique consists of the random and independent selection within two different levels of sampling. The 
first level requires the identification of a certain number of local immigrant meeting places distributed across the municipality (299 locations for Ecuadorians). Centers include the following 13 categories: police/passport/foreigners' offices, other public offices (population registers, post offices), consulates, first aid centers (public canteens, dormitories), medical/health assistance centers (hospitals, specific non-profit organizations dealing with health related problems of immigrants like Naga), legal assistance centers, places organizing lessons of Italian as a second language, training centers, places furnishing services for immigrants (phone centers, money transfer), ethnic stores, markets and malls, entertainment places (ethnic and non-ethnic like discos, restaurants, bars, cinemas), open meeting points (stations, parks, squares, etc.). This set of centres, conveniently identified by means of a preliminary analysis of the local reality by the institute ISMU (with years of experience in this form of sampling), represents a set of heterogeneous environments which all the Ecuadorians in Milan are expected to attend, with contact once or several times per week. The second level of sampling refers to the individuals sampled in the various local centres, who are asked to respond to an additional questionnaire about their attendance to all the reference centers in order to be able to construct the corresponding attendance profile. The universe of immigrants present at the time of the survey is thus made up of a list of $\mathrm{H}$ statistical units, each of which represents a set of contacts with a local centre (Blangiardo, 1999).

${ }^{9}$ Fieldwork took double the time in the Spanish cities because, unlike the Italian sample, the sampling was based on simple random sampling of named individuals extracted from the local population registers, which include unauthorized migrants as well. Thus, interviewers in Spain visited specific households in search of a given individual, and had a very strict protocol of revisits before giving up on any sample record. This sampling method was not feasible in Italy because of the inexistence of an adequate sampling frame, as there is no register of residents that adequately covers immigrants, especially unauthorized ones. Obviously, nominal samples take longer to complete than samples based on centres of aggregation (see previous note). Moreover, the survey in the two Spanish cities was conducted in-house by a fieldwork operations team purposely set up for this survey - as there was at the time no professional polling institute that had a credible experience with undertaking representative surveys of immigrant population whereas it was conducted by an experienced institute in Italy (ISMU).

${ }^{10}$ During fieldwork coordination, any individual born in Spain with a parent born in Ecuador was considered a $2^{\text {nd }}$ generation individual and reassigned to the Ecuadorian subsample. Equally, individuals born in Ecuador of both parents born in Spain were reassigned to the 'autochthonous' group. The gross sample included 600 named Ecuadorian individuals in each city. Due to fieldwork difficulties, in the end, only 213 interviews in Barcelona and 237 in Madrid were obtained from the originally sampled individuals. An additional 45 interviews in Barcelona and 34 in Madrid were obtained by substitution within the dwellings of the sampled individuals, and 28 interviews in Madrid were achieved through the same spatial sampling method of 'centres of aggregation' used in Milan. All analyses for the Spanish cities have controlled for the sampling method and no significant effect of selection procedures was found. Thus, we expect that the 
different sampling strategies in Italy and Spain are not altering our results, especially because selection procedures are not obviously related to our dependent variables (political transnationalism).

${ }^{11}$ Abstention rates in the consulates of the three cities for the 2006 presidential elections, according to the Ecuadorian National Electoral Council (Consejo Nacional Electoral, 2009), were as follows: 33.9 in Barcelona, 39.3 in Madrid, and 31.7 in Milan. Thus, official results confirm our survey results of higher turnout rates in Milan than in the other two cities, and we have to bear in mind that consulates cater for areas that are larger than our sampling areas, that were restricted to the municipalities. Given the dates when we conducted fieldwork, some of the respondents in our survey answered in relation to the legislative and presidential elections of October/November 2006 and some in relation to the elections to the new Constitutional Assembly of 28th September 2007. This, together with the fact that the consulates calculate turnout on the basis of registered voters and not eligible voters, accounts for the differences between our survey and official results in the estimation of the exact turnout rates.

${ }^{12}$ Certainly, the recency of the Ecuadorian immigration and the fact that second generations are still small in size means that the situation in relation to transnational practices is likely to be fluid. However, the expectation from the literature would be that second generations are less engaged in transnational practices than their parents' generation, and not the opposite. Consequently, our study should reflect, if anything, the moment in which transnational engagement should be at its 'peak' for demographical reasons.

${ }^{13}$ We performed three separate factor analyses for each of the cities. All of them included the following items: interest in Ecuadorian politics, attachment to Ecuador, talking about Ecuadorian politics, feeling informed about Ecuadorian affairs, reading newspapers about Ecuadorian affairs, voting in the previous Ecuadorian elections, and participating in any of the 12 forms of nonelectoral political participation listed in Table 2. We examined both the non-rotated and rotated (Varimax with Kaiser normalization) maximum likelihood extractions. In all three cities the solution was a three factor solution (with an Eigenvalue of at least 1) that accounted for between 60 and 69 percent of the variance. However, the factors were not easily interpretable other than pointing to the fact that political awareness orientations formed their own separate dimension to attachment, voting and non-electoral participation.

${ }^{14}$ We have run three separate models for each city and the results are very similar.

${ }^{15}$ Our item of political efficacy enquires about politics in general and does not specify if referred to the politics of the country of residence or the country of origin.

${ }^{16}$ The correlation between involvement in associations formed by a majority of Ecuadorians and the indicators on ethnic bonding in the household or with acquaintances is relatively low, thus the inclusion of both indicators in the regression poses no problems of collinearity. 